Atıf Bilgisi: Bal, D. ve Bayçu, S. (2021). Göz izleme yöntemi: Halkla ilişkiler ve reklamcılık bağlamında genel bir bakış. INIF E-Dergi, 6(2), 286-305.

\title{
GÖZ İZLEME YÖNTEMİ: HALKLA İLISSKILLER VE REKLAMCILIK BAĞLAMINDA GENEL BİR BAKIŞ
}

\author{
Arş. Gör. Döndü $B A L^{*}$ \\ Doç. Dr. Sevil BAYÇU $U^{* *}$ \\ DOI: 10.47107/inifedergi.978329
}

Arasstırma Makalesi ${ }^{* * *}$

Başvuru Tarihi: 03.08.2021

Kabul Tarihi: 14.09.2021

\section{$\ddot{O} z$}

İletişim dünyasında oluşturulan materyallerin hedef kitle tarafindan fark edilmesi, hedef kitlenin bu materyallere bilinçli ve istekli bir şekilde angaje olmaları kritik önem taşımaktadır. Bu noktada; dikkat, odaklanma, meşgul olma, fark etme, hatırlama, bilgi işleme süreçlerine dâhil etme gibi kavramlar iletişim araştırmaları için önde gelen çalışma konuları arasına girmektedir. Sözü geçen bu unsurların hedef kitlede tetiklenebilmesi için ise her şeyden önce iletişim materyallerinin hedef kitlenin görsel algı alanı içerisinde yer alması gerekmektedir. Görsel alan içerisinde çeşitli iletişim materyallerine maruz bırakılan alıcılar görsel algı verilerini beyin sinirlerine iletmekte ve burada çeşitli bilişsel süreçler oluşturulmasına zemin oluşturmaktadır. $\mathrm{Bu}$ sürecin belirlenebilmesi, detaylı incelenebilmesi içinse en objektif ve güvenilir yöntemlerin başında göz izleme yöntemi gelmektedir. Son zamanlarda psikolojiden pazarlamaya, reklamdan halkla ilişkilere çok çeşitli alanlarda popüler bir araştırma yöntemi haline gelen bu yöntem sayesinde; katılımcıların göz hareketleri, iletişim materyalleri üzerinde odaklandıkları alanlar, dikkat düzeyleri, hatırlama düzeyleri gibi önemli araştırma verilerine ulaşılabilmektedir. Özellikle halkla ilişkiler ve reklamcılıkta görülen yeni yaklaşımlara paralel olarak kullanılan yöntemler çeşitlenmiş, göz izleme yöntemi de bu yöntemler arasında yerini almıştır. Bu çalışma ile yerli literatürde yeni yeni önem kazanmaya başlamış göz izleme yöntemi hakkında genel bir bakış kazandırılmak hedeflenmiştir. Yöntemin çeşitli kaynaklarda nasıl tanımlandığı, göz izleme yönteminde kullanılan ve araştırma sonuçlarına veri sağlayan ölçüm metrikleri, göz izleme verilerinin nasıl görselleștirildiği, göz izleme yönteminde sabitlenme-tanımlama algoritmaları, göz izleme ve dikkat ilişkisi, göz izleme cihazları ve türleri, göz hareketlerini etkileyen faktörler, tipik bir göz izleme prosedürünün ne olduğu bu kapsamda önem verilen konuların başında yer almaktadır. Ayrıca, yöntemin reklam ve halkla ilişkiler alanında gerçekleştirilmiş örnek çalışmalara ve göz izleme yönteminde kayıp veri, veri kalitesi ve geçerlilik olgusu da son derece önemlidir. Çalışmanın, göz izleme yöntemi ile ilgilenen araştırmacılar için temel bir bilgi kaynağı olması beklenmektedir.

Anahtar Kelimeler: Göz İzleme Yöntemi, Dikkat Ölçümlemesi, Reklam, Halkla İlişkiler

\footnotetext{
Anadolu Üniversitesi, İletişim Bilimleri Fakültesi, Halkla İlişkiler ve Reklamcılık Bölümü, E-mail: dondubal@anadolu.edu.tr, ORCID ID: 0000-0002-6019-3831

** Anadolu Üniversitesi, İletişim Bilimleri Fakültesi, Halkla İlişkiler ve Reklamcılık Bölümü, E-mail: suzoglu@anadolu.edu.tr, ORCID ID: 0000-0003-0865-6007

**** Yazar / yazarlar, makalede araştırma ve yayın etiğine uyulduğuna ve kullanılan fikir ve sanat eserleri için telif hakları düzenlemelerine riayet edildiğine yönelik beyanda bulunmuştur.
} 


\title{
EYE TRACKING METHOD: AN OVERVIEW IN THE CONTEXT OF PUBLIC RELATIONS AND ADVERTISING
}

\begin{abstract}
In the world of communication, it is critical that the materials created are noticed by the target audience and the target audience engages in these materials consciously and willingly. At this point, concepts such as attention, focus, being busy with the materials, noticing, remembering, including in information processing are among the leading study topics for communication research. In order for these aforementioned elements to be triggered in target audiences, first of all, communication materials must be located within the visual perception area of the target audience. Receivers exposed to various communication materials in the visual field transmit visual perception data to the brain nerves and therese create basis for the formation of various cognitive processes. In order to determine and examine this process in detail, eye tracking is one of the most objective and reliable methods. Thanks to this method, which has recently become a popular research method in a wide variety of fields from psychology to marketing, from advertising to public relations, important research data such as participants' eye movements, areas of focus on communication materials, attention levels, and recall levels can be accessed. In particular, the methods used in parallel with the new approaches seen in public relations and advertising have also diversified, and the eye tracking method has taken its place among these methods. With this study, it is aimed to gain an overview about the eye tracking, which has just started to gain importance in the domestic literature. These ara the most important issues in this context: how the method is defined in various sources, measurement metrics used in eye tracking and providing data for research results, how eye tracking data is visualized, fixation-description algorithms in eye tracking, eye tracking and attention relationship, eye tracking devices and types, factors affecting eye movements, what a typical eye tracking procedure is. In addition, case studies of the method in the field of advertising and public relations and the phenomenon of missing data, data quality and validity in eye tracking are also extremely important. The study is expected to be a basic source of information for researchers interested in eye tracking.
\end{abstract}

Keywords: Eye Tracking, Attention Measument, Advertising, Public Relations

\section{Giriş}

Son zamanlarda, hedef kitle davranışlarını anlamak için nörofizyolojik yöntemlerin önem kazandığ görülmektedir. Bu konuda, insan duygularının, bazen anlık ve otomatik tepkiler verdiğine ve insanların bunları doğru sözcüklerle açıklamakta zorluk yaşadığına dikkat çekilmektedir. Bir başka ifadeyle, bireylerin kendilerini anlatarak elde edilen verilerin kişisel olacağına ve gerçeği yansıtmama ihtimali taşıdığına vurgu yapılmaktadır. Bu noktada, nörofizyolojik ve biyolojik yöntemler insanların zihinsel süreçlerine ulaşmayı hedeflemektedir. Bu durum, insan zihninin kara kutusunu incelemek olarak tabir edilmekte; EEG, FMRI, kalp atışı, yüz ifadeleri, göz izleme gibi yöntemlerin ön plana çıkmasını sağlamaktadır. Bu yöntemlerden ise özellikle göz izleme yöntemi ile daha objektif ve güvenilir ölçümlemelerin yapılabileceği ileri sürülmektedir (Pozharliev vd., 2017, s. 351-352; Ju ve Johnson, 2010, s. 160; Duchowski, 2002, s. 455).

Göz izleme; marka denkliği, bölümleme, yeni ürün geliştirme, fiyatlandırma ve tanıtım kararları, sosyal medya çalışmaları gibi pazarlama uygulamalarında kullanılmak için de önemli potansiyeli olan bir yöntem olarak görülmektedir (Santos vd., 2015, s. 32). Bugün, büyük şirketlerin birçoğu görsel pazarlama faaliyetlerini daha etkili hale getirmek için tüketicilerin ne gördüklerini yakından takip etmektedir. Özellikle Kraft Foods, PepsiCo, Pfizer, P\&G, ve Unilever gibi markalar bu yöntemin önde gelen kullanıc1ları arasında gösterilmektedirler (Wedel ve Pieters, 2008, s. 123). Halkla ilişkiler ve reklamcılık alanlarında meydana gelen yeni yaklaşımlarla beraber de hedef kitlenin göz hareketlerinin ölçümlenmesi gibi nörobilimsel araştırma yöntemlerinin önemi daha da artmaktadır. Burada göz izleme, kullanıcıların görsel tarama davranışlarının nesnel olarak elde edilmesi için kullanılmaktadır (Resnick ve Albert, 2014, s. 209; King vd., 2019, s. 149). Bu yaklaşım üzerinde, katılımcılara müdahale edilmemesi, göz hareketlerinin bilinçli ve bilinçsiz olarak kaydedilmesi etkili olmaktadır (Kumar vd., 2016, s. 1). Bu kullanımı daha iyi açıklayabilmek için öncelikle göz izleme yönteminden söz etmek gerekmektedir. 


\section{Göz İzleme Yöntemi}

Lierle, kişinin gözünün baktığı noktanın, tam o anda zihninde var olan düşünceyi yansıttığını belirtmektedir (2017, s. 4). Dolayısıyla, göz izleme; gözlemlenen bireyin, 'görsel ve bilişsel süreçlerine açılan bir pencere' olarak son yıllarda popülerlik kazanmıştır (Salvucci ve Goldberg, 2000, s. 71). Göz hareketleri, insan beyninin nesneleri daha çabuk fark etmesini sağlamaktadır (Myers vd., 1991, s. 14). Göz izleme, bireyin dijital ya da fiziki bir uyaranı izlerken göz hareketlerinin ölçüldüğü yöntem olarak tanımlanmaktadır (Wästlund vd., 2010, s. 43). Bu yöntem, görsel davranış ölçümlemeleri için objektif veri toplama firsatı yaratmaktadır. $\mathrm{Bu}$ yaklaşımda, görsel davranış ile kastedilen, göz hareketleri ve pozisyonlarının ölçümlenmesidir. Göz izleme yöntemi ile saniyede 25 bakış noktasından 2000 bakış noktasına kadar değişen hızlarda göz pozisyonları kaydedilebilmektedir (King vd., 2019, s. 149-150). Bu noktada; göz izleme, göz hareketlerinin ölçümlenmesi için doğru yöntemlerden biri olarak görülmektedir (Cao vd., 2019, s. 90). Burada, göz izleme yöntemi ile algısal sürecin teknik ekipman yardımıyla edinilmesi fırsatının yaratılacağı düşünülmektedir (Litfin vd., 2017, s. 32).

Dünyanın algılanması için gözler devamlı hareket etmeye ve daha fazla bilgi elde etmek için etkili bir şekilde etrafını taramaya ihtiyaç duymaktadır (Gwizdka vd., 2019, s. 742). Bu anlama ve anlamlandırma sürecinde, göz izleme verileri araştırmacılara iki tür içgörü sunmaktadır: doğrudan ve dolaylı. Doğrudan içgörüler, insanların ekranda nereye ve nasıl baktığına odaklı bilgi içermektedir (sabitlenme yerleri ve bunların zamanlamaları veya süreleri gibi). Dolaylı içgörüler, insan vizyonu ve nöro-fizyoloji bilgisi temellidir. $\mathrm{Bu}$ tür bilgi, göz izleme ölçümleri ile bilişsel veya duygusal fenomenler arasında ilişkiler kurmayı sağlamaktadır (Gwizdka vd., 2019, s. 746).

Erken dönem göz izleme çalışmalarında göz hareketleri video olarak kaydedilmiştir. Okuyucunun göz hareketlerini çevrimiçi olarak takip edebildiğimiz için video kayıtları tanımlayıcı niteliktedir. Ancak genel bir sonuç çıkarmak için videonun ağır çekimde izlenmesi ve belirli değişkenlerin kare kare kodlanması gerekmekteydi. Zamanla göz izleme cihazı ile donatılmış kasklar kullanılmaya başlanmıştır. Bu durum manuel kodlama gerekliliğini ortadan kaldırmıştır. Bilgisayarlar kod çözme işlemini gerçekleştirmeye başlamıştır (Holsanova vd., 2006, s. 73).

Göz izleme yönteminin psikolojik çalışmalarla ve okuma eylemi üzerine gerçekleştirilen çalışmalarla ön plana çıkmaya başladığına vurgu yapılmaktadır. Bir asırdan fazla bir süre önce ilk olarak psikologlar gözün temel mekanizmalarını belirlemişlerdir. Aradan geçen yıllar insanoğlunun algılama, izleme görsel uyaranları işleme süreçlerine dair anlayışını güçlendirmiştir (Gwizdka vd., 2019, s. 742). Okuma üzerine göz izleme deneylerinin ilki ise 1989 yılına uzanmaktadır. Kupper 60 okuyucu ile görsel unsurlara yazılı metinlerden daha fazla bakılıp bakılmadığını, fotoğraflar için sayfanın en uygun yerin neresi olduğunu belirlemeye yönelik bir çalışma gerçekleştirmiştir. 1996 yılında da Josephson, bir sayfadaki fotoğrafın konumunun tüketici dikkatini renklerden daha fazla etkilediğini ortaya çıkarmıştır (Cantoni vd.,2011, s. 3). 1980'lerde kişisel bilgisayarlar gelişmeye başladığında, araştırmacılar göz izleme alanını insan-bilgisayar-etkileşimi konularına dâhil etmeye başlamışlardır (Schiessl vd., 2003, s. 1 2). 


\section{Görsel 1. 2000’li Yıllarda Kullanılan Bir Göz İzleyici ile Gazete Okuyan Bir Katılımcı (Göz İzleyici Bir SMI Head Set)}

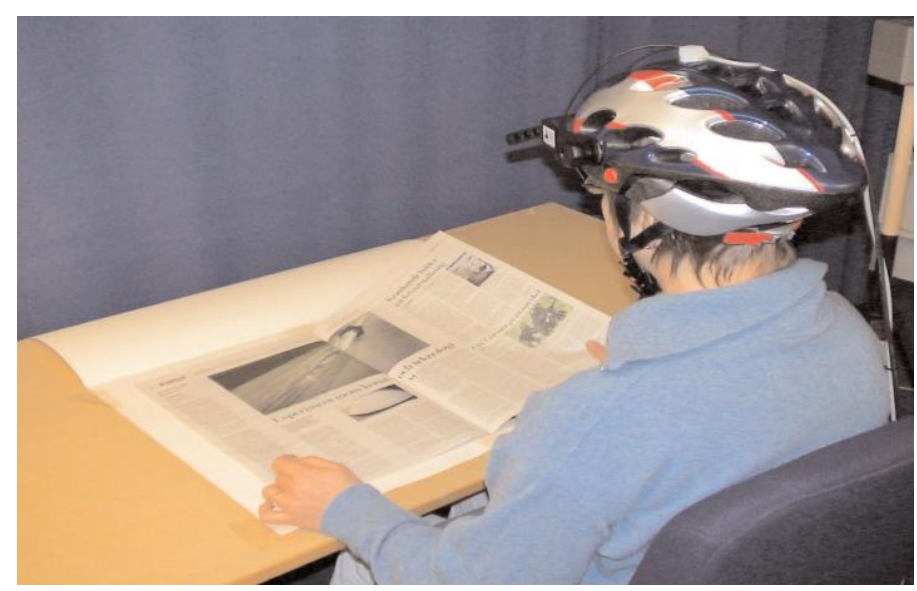

Kaynak: Holsanova vd., 2006, s. 74.

İletişim alanı özelinde göz izleme yöntemi ile gerçekleştirilen araştırmalara bakıldığında; televizyon programlarındaki ürün yerleştirmelerin gösterim şekillerinden (Boerman vd., 2015, s. 196), web dizinlerindeki reklamların konumlandırıldı̆̆ yerlere (Cao vd., 2019, s. 89), reklamlara yönelik görsel dikkatten (Ju ve Johnson, 2010, s. 159), sponsorluk iletişimine (Rumpf ve Breuer, 2018, s. 531), reklamda yer alan uyarı mesajlarına karşı tüketici dikkatinden (Krugman vd., 1994, s. 39), kurumsal sosyal sorumluluk raporlarına (Litfin vd., 2017, s. 30), bireylerin gazete okuma biçimlerine (Holsanova vd., 2006, s. 65), banner reklamlardan (Lee ve Ahn, 2012, s. 119; Owens vd., 2011; Resnick ve Albert, 2014), paket tasarımına (Wästlund vd., 2010, s. 42), online alışveriş ortamlarında tüketici kararlarına (Chae ve Lee, 2013, s. 83) kadar çok geniş konularda çalışmalara rastlanmaktadır. Kısacası, 2010 yılından itibaren iletişim alanında göz izleme araştırmalarının öneminin artarak devam ettiği görülmektedir.

\section{Göz İzleme Yönteminde Kullanılan Metrikler}

Göz izleme yöntemi, ölçüm sırasında kullanılan metrikler (ölçümlenen unsurlar) açısından oldukça zengin bir yöntemdir. Bu yöntemde kullanılan metrikler Tablo 1'de sunulmuştur:

Tablo 1. Göz İzleme Yönteminde Kullanılan Metrikler

\begin{tabular}{|c|c|}
\hline Metrik & Açıklaması \\
\hline $\begin{array}{l}\text { Sabitlenme-Temelli Metrikler } \\
\text { (Fixation-Based Metrics) }\end{array}$ & $\begin{array}{l}\text { Bir ilgi alanı (AOI) }{ }^{1} \text { üzerindeki, sabitlenme sıklı̆̆ı (fixation } \\
\text { frecuency), sabitlenme saylsı (fixation count), ilk sabitlenme } \\
\text { noktası (location of the first fixation), gözlem/ziyaret/bekleme } \\
\text { saylsı (observation/visit/dwell count) bu gruptaki metriklerdir. } \\
\text { Burada oran düzeyinde bir ölçümleme söz konusudur. }\end{array}$ \\
\hline $\begin{array}{l}\text { Zaman-Temelli Metrikler (Time-Based } \\
\text { Metrics) }\end{array}$ & $\begin{array}{l}\text { Sabitlenme süresi (fixation duration/dwell time), } \\
\text { gözlem/ziyaret/bekleme süresi (observation/visit/dwell duration), } \\
\text { toplam sabitlenme süresi (total fixation duration) ve ilk } \\
\text { sabitlenme süresi (time of the first fixation) bu gruptaki } \\
\text { metriklerdir. }\end{array}$ \\
\hline $\begin{array}{l}\text { Hareket-Temelli Metrikler (Movement-Based } \\
\text { Metrics) }\end{array}$ & $\begin{array}{l}\text { Kısa ve hızlı hareketler (saccades) ve tarama yörüngesi } \\
\text { (scanpath) bu grupta yer alan metriklerdir. }\end{array}$ \\
\hline Diğer Metrikler (Other Metrics) & $\begin{array}{l}\text { Gözbebeği büyüklü̈̆̈̈̈/gözbebeği büyümesi, göz kırpma hızl, } \\
\text { katılımcl yüzdesi (participant \%) vb. bu grupta yer alır. }\end{array}$ \\
\hline
\end{tabular}

Kaynak: King vd., 2019, s. 151-153; Lee ve Ahn, s. 127; Duerrschmid ve Danner, 2018, s. 284.

Göz izleme yönteminde kullanılan bu metrikler son derece önemlidir. Tablo 1'de yer alan kavramları kısaca açıklamakta yarar vardır (Salvucci ve Goldberg, 2000, s. 71;

${ }^{1}$ AOI: Area of Interest 
Wedel ve Pieters, 2008, s. 124; King vd., 2019, s.153; Wästlund vd., 2010, s. 43; Cao vd., 2019, s. 90; Cantoni vd., 2011, s. 3; Lierle, 2017, s. 19; Duerrschmid ve Danner, 2018, s. 284; Krugman vd., 1994, s. 44):

Kısa ve hızlı hareketler (saccades): Gözün noktalar arasındaki hızlı atlama hareketlerini ifade etmektedir. Genellikle 20-40 ms hızla gerçekleşmektedir. İnsan bedeninin en hızlı hareketidir ve insanların günde ortalama 70 bin ile 100 bin arası sayıda bu göz hareketini gerçekleştirdiği belirtilir. Araştırmacılar, bilişsel detaylandırmayı kısa ve hızlı hareketlerin sayısı ile operasyonel hale getirmektedirler.

Gözün sabitlenmesi (fixation): Gözün göreli olarak durgunlaştığı anlardır. Bir başka ifadeyle, ilgilenilen alanlar üzerindeki duraklamaları ifade etmektedir. Genellikle 200-500 ms sürmektedir. Gözün sabitlenmesi, algılamadan sorumlu sayılır ve bireyin bilişsel stratejisinin bir yansıması olarak kabul edilmektedir.

Sabitlenme süresi (fixation duration): Görsel bilgi üzerinde geçirilen süreyi ifade etmektedir.

Ilk sabitlenme noktast (location of the first fixation): Gözün ilk sabitlendiği noktadir.

Tarama yörüngesi (scanpath): Bir uyaran karşısında gösterilen gözün sabitlenmesi ve hızlı hareketlerinin oluşturduğu şemaya denir. Bir başka deyişle; tarama yörüngesi, kişinin bir şeye bakarken gözünün takip ettiği yörüngedir. Bir şeye bakarken kullanıcının gözlerinin izlediği yol olarak da tanımlanabilir.

Ilgi Alanı Tanımlanması (AOI-Area of Interest Identification): Özel hedef alanlar üzerinde gerçekleşen göz sabitlenmelerinin tanımlanmasını ifade etmektedir. İlgi alanı bir metindeki görsel, bir dükkândaki raflar vb. olabilir. Ölçülebilir tarama yörüngesi yaratmak için öncelikle görsel, başlık, iletişim bilgisi, logo vb. gibi ilgi alanları oluşturulur.

Ilk sabitlenme zamanı (time of the first fixation): Bir ilgi alanı içerisinde testin başlamasından ilk sabitlenmenin başlangıcına kadar geçen süredir. sayısıdır.

Sabitlenme sayısı (fixation count): Bir ilgi alanı içerisindeki sabitlenmelerin

Toplam sabitlenme süresi (total fixation duration): Bir ilgi alan1/alanlar1 içerisindeki bir katılımcının tüm sabitlenme sürelerinin toplamıdır.

Gözlem/ziyaret/bekleme sayısı (observation/visit/dwell count): Bir katılımcının bir ilgi alanı içerisine girme sayısıdır.

Gözlem/ziyaret/bekleme süresi (observation/visit/dwell duration): Bir ilgi alan1 içerisindeki her bir bireysel ziyaretin süresidir.

Katılımcı yüzdesi (participant \%): Bir ilgi alanı içinde en az bir kez sabitlenmiş katılımcıların yüzdesi olarak tanımlanmaktadır.

Göz izleme araştırması gerçekleştirilirken kullanılan bu metriklerden elde edilen verilerin daha anlamlı hale gelebilmesi için ise görselleştirilmesi gerekir.

\section{Göz İzleme Verilerinin Görselleştirilmesi}

Göz izleme verilerinin görselleştirme yollarından biri, görsel ilginin etkin noktalarının gösterildiği 1sı haritası grafiğidir. Bir renk kodu kullanarak uyaranın her alanında birkaç katılımcının toplam sabitlenmelerini göstermektedir (Bkz. Görsel 1) (Duerrschmid ve Danner, 2018, s. 285). Başka bir ifadeyle kişinin en sık ve uzun baktığ alanlar kırmızı, daha orta düzeyde sık baktığı alanlar sarı veya turuncu, en az baktığı 
alanlar ise yeşil renkte gösterilir. Hiçbir renk olmayan alanlar katılımcının hiç bakmadığı alanları göstermektedir.

\section{Görsel 2. Göz İzleme Verisini Görselleştirmek İçin Isı Haritası Örneği}

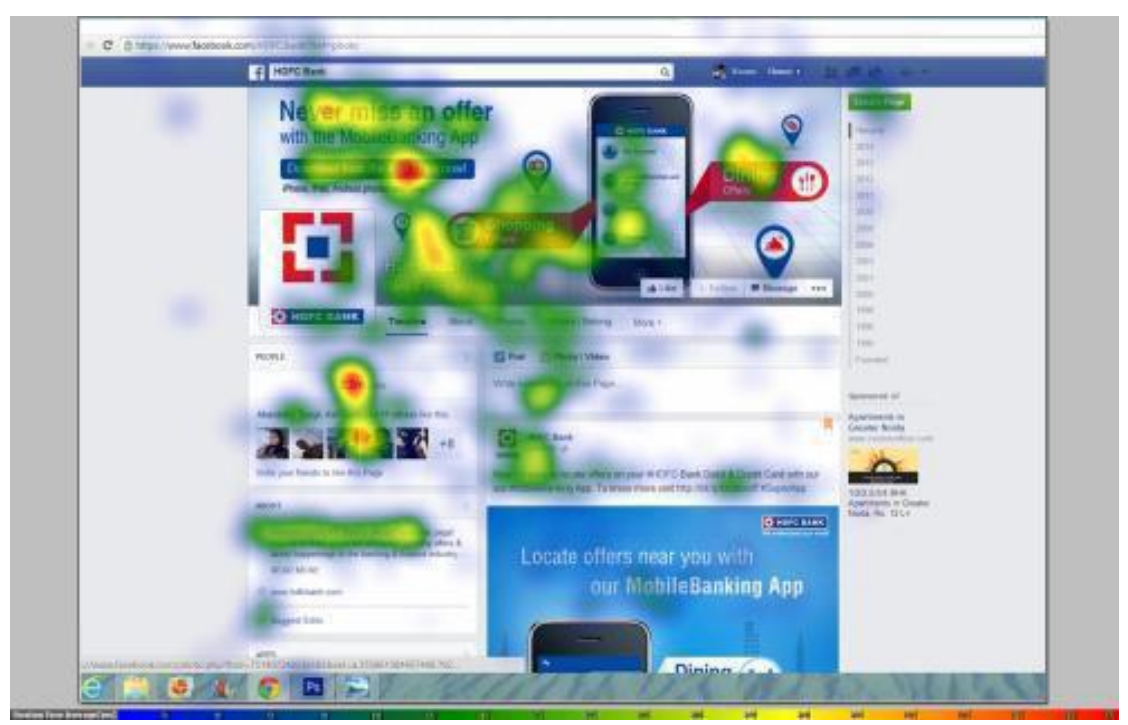

Kaynak: Kumar vd., 2016, s. 4.

Örnekte yer alan kırmızı noktalar katılımcının en fazla baktığı noktaları gösterirken, yeşil en az baktığı noktaları göstermektedir. Sarı ve turuncu renkler ise orta sıklıkta baktıkları alanları göstermektedir. Renklendirmenin olmadığı alanlar ise katılımcının hiç bakmadığı alanlardır. Bu örnekte katılımcı sayfanın sol tarafına sabitlenmiştir.

Göz hareketi verilerinin analizi için önemli bir araç da görselin ayrı olarak analiz edilmesi gereken önemli alanlarını tanımlayan ilgi alanlarının (AOI) kullanılmasıdır. Göz izleyici (Eye tracker) yazılımı kullanılarak görüntü üzerinde ilgi alanları çizilebilir ve ardından tanımlanan alanlara ilişkin göz izleme verileri istatistiksel olarak analiz edilebilir (Bkz. Görsel 2) (Duerrschmid ve Danner, 2018, s. 285). İstatistiksel analizleri doğru yapabilmek için araştırmaya konu olacak görselin, başlığın, metnin, iletişim bilgilerinin, varsa sponsorların, yazı karakterlerinin (bold, italik veya büyük harflerle yazılı kısımların), kutucuklar içindeki özet/dikkat çekici bilgileri vb. içeren ilgi alanlarını netleştirmekte yarar vardır. Bu bilgiyi bir örnekle açıklamak gerekirse; 


\section{Görsel 3. Bir Görseldeki İlgi Alanı- AOI Tanımlaması}

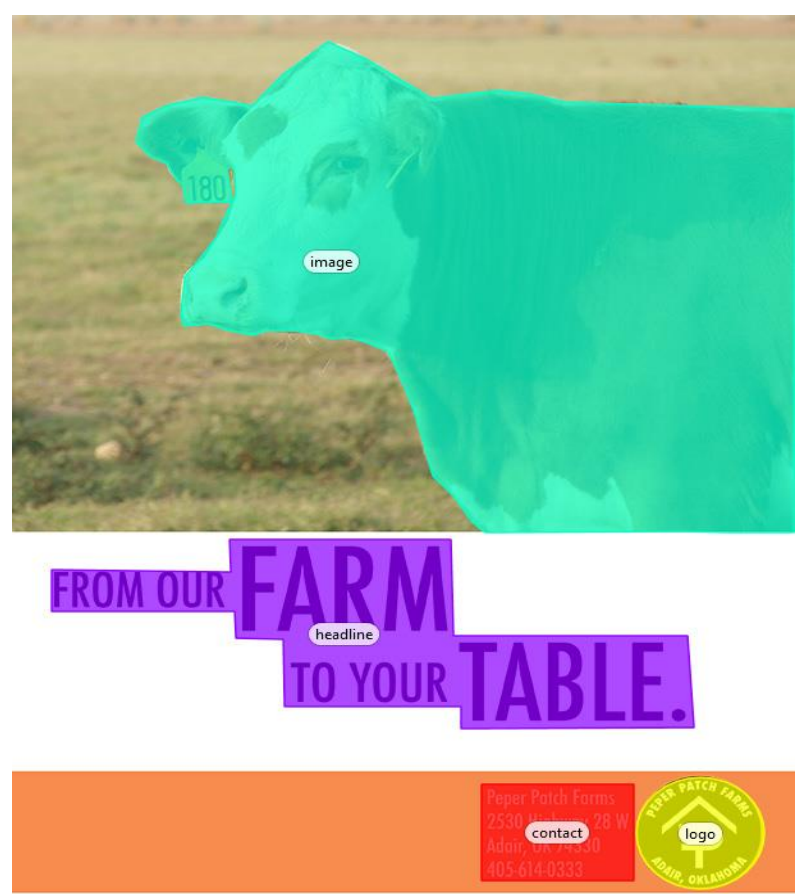

Kaynak: Lierle, 2017, s. 26.

Görsel 3'te; görsel (image), başlık (headline), iletişim bilgileri (contact) ve logo olarak 4 ilgi alanı noktası belirlenmiş̧ir.

Göz izleme verilerini görselleştirmek için başka bir seçenek de, bir zaman çizelgesinde sabitlenmelerin gösterilmesidir. Bu tür bakış dizileri, bir katılımcının tarama yolunu (scan path) ve arama davranışını (search behavior) gösterir. Her sabitlenme bir nokta olarak gösterilir, noktaların içindeki sayı sabitlenmenin gerçekleşme sırasını ve noktanın çapı sabitlemenin süre açısından uzunluğunu temsil etmektedir (Bkz. Görsel 3) (Duerrschmid ve Danner, 2018, s. 285).

\section{Görsel 4. Bakış Davranışını Görselleştirmek İçin Bakış Dizileri Örneği}

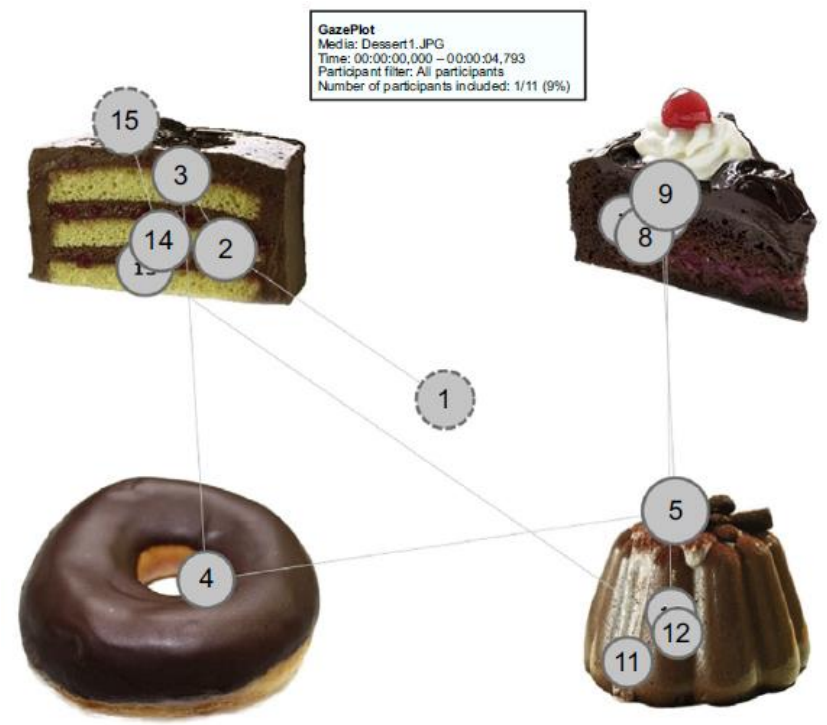

Kaynak: Duerrschmid ve Danner, 2018, s. 286. 
Görsel, katılımcının gözünün bakış sırasını bir dizi halinde göstermektedir. Katılımcı en fazla bakış sayısını sol üstte yer alan üç katlı çikolatalı pastaya vermiş, ilk olarak o pastaya bakmış daha sonra sağ alttaki pastaya gözleri gelmiştir.

\section{Göz İzleme Yönteminde Sabitlenme Tanımlama Algoritmaları}

Günümüzün en önemli göz hareketi ölçüm yöntemi, göz bebeği ve kornea yansıma yöntemidir. Işık, göz bebeklerinden göze ve retinaya ulaşırken, gözün dışını kaplayan kornea 1şı̆̆ yansıtmaktadır. Ortam ışı̆̆ı ne kadar parlaksa, göz bebeği o kadar küçülmekte ve ölçüm o kadar hassas olmaktadır. Kızılötesi ile çalışan bir göz izleyici, bakış konumunu tam olarak hesaplamak için kameralar, projektörler ve algoritmalardan oluşmaktadır. Projektörler, katılımcının gözlerinde kısmen yansıtılan bir yakın kızılötesi 1şık deseni oluşturmaktadır. Kameralar, kullanıcının gözlerinin yüksek kare hızlı görüntülerini ve daha sonra matematiksel görüntü işleme algoritmaları tarafından analiz edilen yansıma modellerini almaktadır. Sonunda bilgisayar monitöründe veya diğer görsel uyaranlarda gözlerin konumu ve bakış noktası hesaplanmaktadır (Duerrschmid ve Danner, 2018, s. 282-283). Bu süreçte algoritmalar göz izleme yönteminde önemli bir unsur olarak ortaya çıkmaktadır.

Sabitlenme tanımlaması (fixation identification)- sabitlenme ve hizlı hareketlerin göz izleme protokollerinde ayrılması ve etiketlenmesi- göz hareketleri veri analizinin önemli bir kısmını oluşturmaktadır ve üst düzey analizler üzerinde önemli etkileri bulunmaktadır. Sabitlenme tanımlaması, gözlemlenen göz hareketleri davranışının istatistiksel tanımlamasıdır. Ham göz hareketi verilerinin ekrandaki sabitlenme noktalarına çevrilmesidir. Salvucci ve Goldberg sabitlenme tanımlama algoritmalarının (fixation identification algorithms) bir sınıflandırmasını gerçekleştirmiş̧lerdir (2000, s. 71):

Tablo 2. Göz İzleme Yönteminde Sabitlenme Tanımlama Algoritmaları Sınıflandırması

\begin{tabular}{|c|c|c|c|c|c|c|}
\hline \multirow{2}{*}{ Kriter } & & \multicolumn{5}{|c|}{ Temsili Algoritma } \\
\hline & & I-VT & I-HMM & I-DT & I-MST & I-AOI \\
\hline \multirow[b]{3}{*}{ Mekânsal } & Hız Temelli & $\mathrm{X}$ & $X$ & & & \\
\hline & Dağılım Temelli & & & $\mathrm{X}$ & $\mathrm{X}$ & \\
\hline & Alan Temelli & & & & & $\mathrm{X}$ \\
\hline \multirow[b]{2}{*}{ Zamansal } & Süreye Duyarlı & & $\mathrm{X}$ & & & $\mathrm{X}$ \\
\hline & $\begin{array}{l}\text { Bölgesel Olarak } \\
\text { Uyarlanabilir }\end{array}$ & & $X$ & $\mathrm{X}$ & $\mathrm{X}$ & \\
\hline
\end{tabular}

Kaynak: Salvucci ve Goldberg, 2000, s. 72.

Algoritmaların sınıflandırılması, göz izleme protokolündeki mekânsal (spatial) ve zamansal (temporal) bilgiyi nasıl kullanıldıklarına göre gerçekleştirilmiştir. Sınıflandırma mevcut algoritmaların karşılaştırılması ve değerlendirilmesi için iyi bir başlangıç olarak görülmektedir. Mekansal özellikler için hız temelli (velocity-based), dağılım temelli (dispersion-based) ve alan temelli (area-based) olmak üzere üç kriter belirlenmiştir. Hız temelli algoritmalar, göz izleme protokolünde hız bilgisini vurgularlar; sabitlenme noktalarının düşük hıza, hızlı hareket noktalarının yüksek hıza sahip olduğu gerçeğinden faydalanırlar. Dağılım temelli algoritmalar, sabitlenme noktalarının genellikle birbirine yakın noktalardan meydana geldiği varsayımıyla, sabitlenme noktası dağılımlarına odaklanırlar. Alan temelli algoritmalar, ilgili görsel hedeflerini temsil eden ilgi alanlarını içerisindeki noktaları tanımlar. Sabitlenmeler, alan temelli algoritmalar için girdi olarak kullanılabildiğinden, ekrandaki yüksek düzey dikkat sabitlenmelerinin temsilcisi olarak düşünülebilirler. Zamansal özellikler için yazarlar, algoritmanın süre bilgisi kullanıp kullanmadığı (duration sensitive) ve uyarlanabilir (locally adaptive) olup olmadığına göre 
iki kriter belirlemişlerdir. Süre bilgisinin kullanımı sabitlenme geçişlerinin nadiren 100 ms'den az sıklıkla 200-400 ms aralığında olduğu gerçeğiyle yönlendirilir. Bölgesel uyarlanabilirlik, belirli bir veri noktasının yorumlanmasının, geçici olarak bitişik noktaların yorumlanmasindan etkilenmesine izin verir. Bu durum, 'sabit gözlü' bireyler ile büyük ve sık göz hareketleri gösterenler arasındaki farkları telafi etmek için uygundur (Salvucci ve Goldberg, 2000, s. 71-72). Kuşkusuz göz izleme araştırmalarında dikkat kavramının da önemsenmesi gereklidir.

\section{Göz İzleme ve Dikkat Kavramı}

Göz izleme yönteminin kullanıldığı araştırmalara bakıldığında yöntemin en çok ilişkilendirildiği unsurların başında dikkat kavramının geldiği görülmüştür. Herhangi bir zamanda görme alanının yalnızca \% 8'i detaylı işleme için uygundur. Bu noktada, gözün dikkat ettiği noktalar kritik önem taşımaktadır. Dikkat, bilginin daha ileri işlenme süreçlerine geçmesi için bir ön koşul, bir geçiş kapısıdır. Optik sinirler aracıllğıyla iletilen bilgi miktarı beynin işleyebileceğinden daha fazla olduğu için beyin bir dikkat mekanizması geliştirir ve bu mekanizmanın dışındakileri görmezden gelir. Dikkat belirli bir nesne ya da noktaya odaklandığı zaman o noktayı ya da objeyi işleme süreci güçlenirken, diğerlerinin işleme süreci durdurulur. Bu noktada dikkatin belirli noktalarda, görsellerde ya da objelerde sabitlendiği ileri sürülür. Başka bir ifadeyle; dikkat göz hareketleri ile yansit1lir. (Wedel ve Pieters, 2008, s. 124-126).

Göz hareketleri, dikkat değiş̧imleri ile yakından ilişkilidir. (Lee ve Ahn, 2012, s. 127). Bireyin bakışı ile dikkati arasında bir uyum olduğu ileri sürülmektedir (Cantoni vd., 2011, s. 3). Göz izleme yönteminde de, kişinin bakış noktası ile bilişsel dikkati arasında bir bağlantı olduğu kabul edilmektedir (King vd., 2019, s. 150). Bu yönüyle; göz izleme yönteminin, dikkatin objektif bir ölçümlemesi olduğu iddia edilmektedir (Krugman vd., 1994, s. 44). Özellikle nörofizyoloji araştırmacıları, dikkat konusunda; göz izleme ve EEG gibi yöntemlerin anket ve derinlemesine görüşme yöntemlerinden daha kesin veriler sağladığına vurgu yapmaktadır (Pozharliev vd., 2017, s. 352). Burada, göz izleme, araştırmacılara görsel davranışı objektif bir şekilde değerlendirilmesi firsatını sunmaktadır. Görsel davranış, genel olarak bakışın konumlandırma ve hareketlerine yönelik ölçümleme ve metrikleri ifade eden bir kavram olarak düşünülebilir. Kavram aynı zamanda görsel algı, görsel işleme ve görsel dikkat gibi unsurları da kapsamaktadır (King vd., 2019, s. 149). Burada, görsel davranış verisi kişinin dikkat süreçlerinin bir ölçümlemesi olarak da kullanılabilir (Holsanova vd., 2006, s. 73).

Görsel davranışı ve görsel dikkati araştırmak için en başarılı gözlem tekniği, birinin nereye ve nasıl baktı̆̆ını belirleme süreci olan göz izlemedir (Duerrschmid ve Danner, 2018, s. 280). Başka bir ifadeyle, göz izleme, görsel dikkatin analizi için bir araçtır ve nöropazarlama perspektifinden, bu yöntem görsel dikkati tüketicilerin bilişsel ve duygusal tepkileriyle ilişkilendirmeye çalışmaktadır (Santos vd., 2015, s. 32). Görsel dikkat, gelen görsel bilgi için eşik bekçisi olarak görülebilir ve bu nedenle görsel bilgi işlemenin çok önemli bir adımıdır (Duerrschmid ve Danner, 2018, s. 280). Bu noktada, göz izleme yöntemi, izleyicilerin yalnızca programa yönelik görsel dikkatinin ölçümlenmesini sağlamaması aynı zamanda belirli bir program içerisindeki özel bir görsel unsura yönelik dikkatinin ölçülmesi imkânını da sunması açısından önem taşımaktadır (Boerman vd., 2015, s. 197). Kuşkusuz bu önem iletişim alanında özellikle reklam ve halkla ilişkiler çalı̧̧malarında hedef kitleye yönelik daha doğru hedeflerle, doğru araçlarla, doğru görsellerle etki yaratabilecek içeriklerin geliştirilmesi açısından değerlidir. İyi bir göz izleme araştırması gerçekleştirebilmek için göz izleme cihazlarının özelliklerine de hâkim olmakta yarar vardır. 


\section{Göz İzleme Cihazları}

Göz izleme yönteminde, ekrana bakarken kullanıcının bakışlarını algılayabilen bir cihaz olan göz izleyici (eye tracker) kullanılmaktadır (Cantoni vd., 2011, s. 2). En eski göz izleyiciler, deneylere katılanlar için kullanışsız ve rahatsız edici ancak göz hareketi mekaniğine ilişkin temel anlayışımızı oluşturmaya yardımcı olan ham mekanik cihazlar olmuştur. Bu cihazlar, yirminci yüzyılın ortalarında teknolojinin gelişmesine paralel olarak daha rafine hale getirilmiş kamera temelli göz izleyicilerin önünü açmıştır. Modern göz izleyiciler artık kızılötesi 1şık kaynaklarını ve kameraları kullanmaktadır (görünür 1şıkla etkileşimi önlemek için) ve daha kullanışlıdırlar (Gwizdka vd., 2019, s. 742). Günümüzde göz izleme sistemi üreticileri arasında ASL- Applied Science Laboratories-, iMotions A/S Biometric Research Platform, Interactive Minds Dresden GmbH, SMI SensoMotoric Instruments $\mathrm{GmbH}$, SR Research (EyeLink) ve Tobii Technology yer almaktadır.

Göz izleme teknolojisinde meydana gelen gelişmelerle cihazların maliyetlerinde de azalmalar meydana gelmiştir. Bu süreçte, tüketicilerin doğal maruz kalma koşulları altında, büyük miktarda uyaranla, yüksek hassasiyet ve düşük maliyetle göz hareketlerini kaydetmesini sağlayan yeni nesil kızılötesi göz takip cihazları (infrared eye trackers) bu yönteme kolaylıklar getirmiştir (Wedel ve Pieters, 2008, s. 123).

Göz izleme yönteminde kullanılan cihazlar genel olarak üç gruba ayrılmaktadır (Duerrschmid ve Danner, 2018, s. 287):

Ekran temelli göz izleyiciler (screen-based eye trackers): Ekran temelli göz izleyicilerde bir monitördeki görsel uyarıcı kullanılır ve göz izleme modülü bir monitöre entegre edilmiş haldedir (Bkz. Görsel 5 ve Görsel 6).

\section{Görsel 5. Ekran Temelli Göz İzleyici Örneği (EyeLink Portable Duo)}

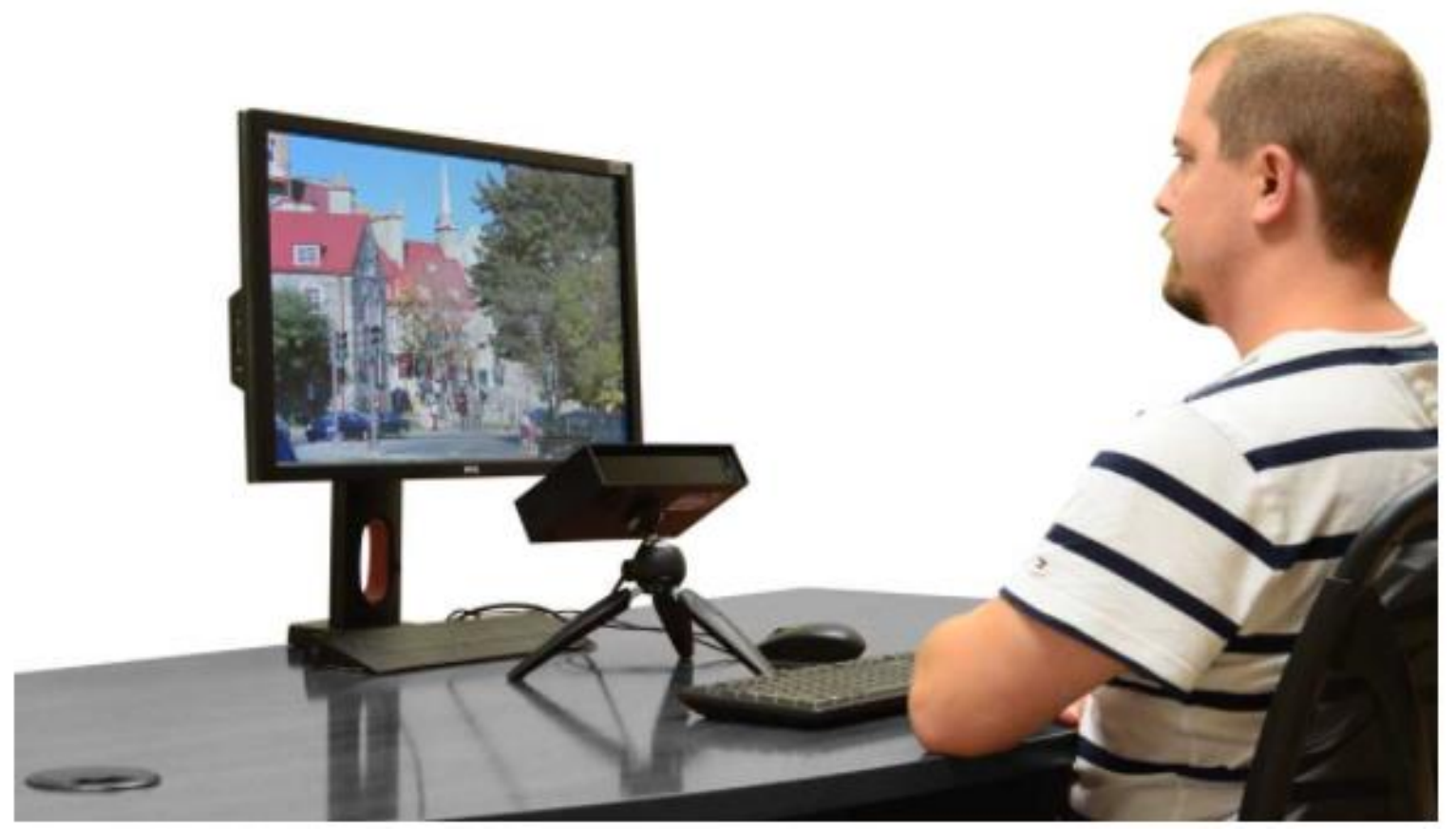

Kaynak: https://www.sr-research.com/eyelink-portable-duo/, (Erişim tarihi: 20. 07. 2021). 


\section{Görsel 6: Interactive Minds Ekran Monteli Göz İzleyicisi}

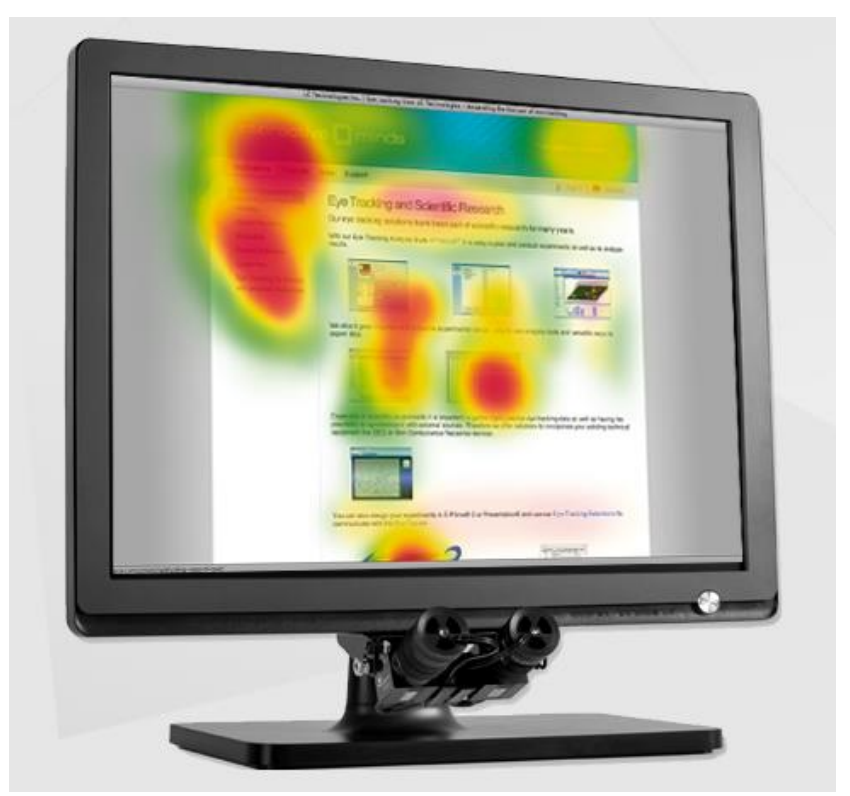

Kaynak: https://www.interactive-minds.com/, (Erişim tarihi: 20.07.2021).

Çevresel göz, izleme modülleri (peripheral eye tracking modules): Görsel uyaranın bilgisayar ekranında değil de gerçek nesne formunda incelendiği çevresel göz izleme modülü katılımcıların raf gibi görsel bir uyaranın önünde dikildiği ya da oturduğu anda kullanılmaktadır (Bkz. Görsel 7).

\section{Görsel 7. iMotions Cihazından Elde Edilen Raf Bakışı Verilerinin Isı Haritasına} Dönüştürülmüş Hali

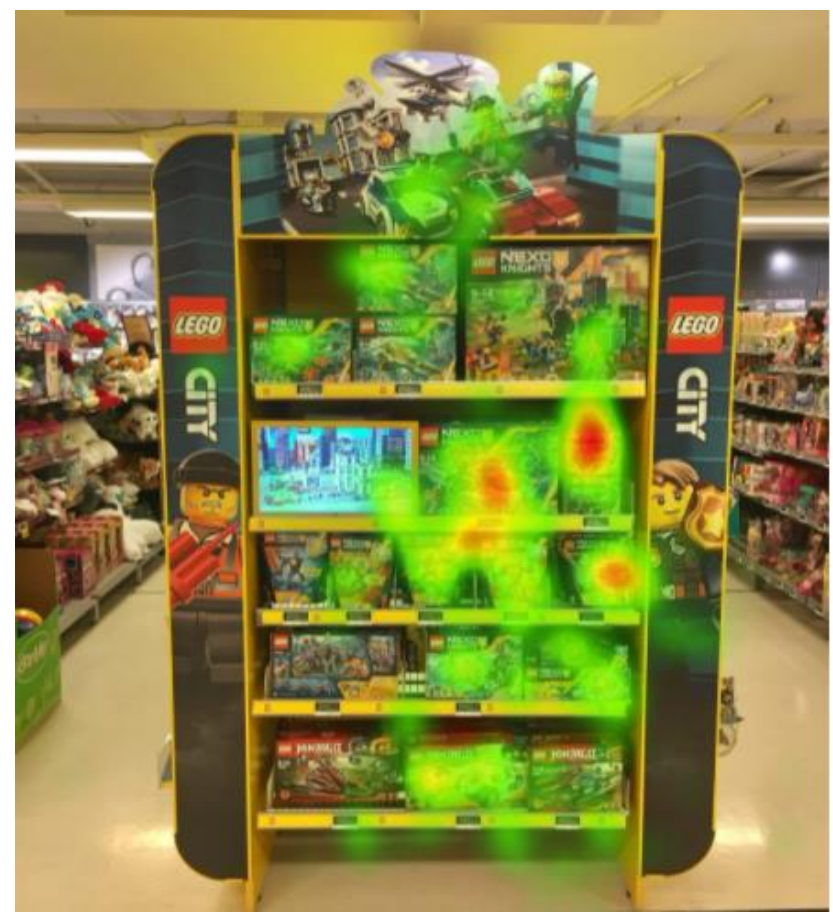

Kaynak: https://imotions.com/blog/how-to-do-product-testing-in-store-shelf-testing/, (Erişim tarihi: 20.07.2021)

Giyilebilir göz, izleyiciler (wearable eye trackers): Genellikle bir tür gözlüğün içine yerleştirilen giyilebilir göz izleyiciler ise bu teknolojiyi bir adım öteye taşımaktadır. Bu cihazlar, katılımcıların serbestçe hareket edebilirken ve nesnelerle etkileşimde bulunurken, 
örneğin süpermarkette alışveriş yaparken veya araba kullanırken, bakma davranışının kaydedilmesine izin vermektedir (Bkz. Görsel 8).

Görsel 8. Giyilebilir Göz İzleyici Örneği (Tobii Pro Glasses 3)

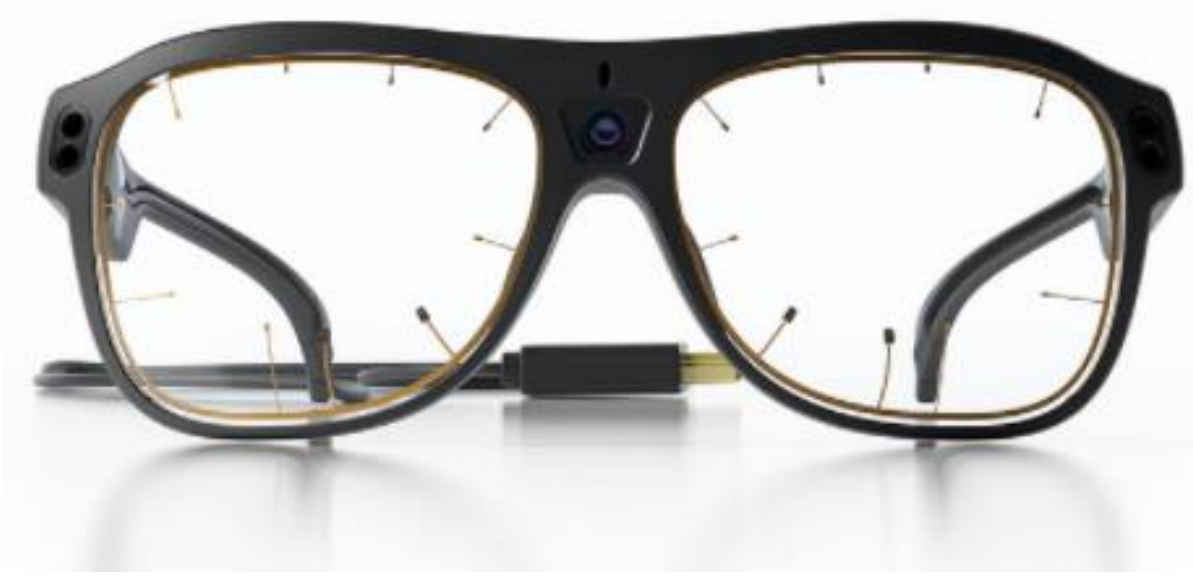

Kaynak: https://www.tobiipro.com/product-listing/tobii-pro-glasses-3/, (Erişim tarihi: 20.07.2021).

Göz izleme araştırması gerçekleştirirken yapılacak araştırmanın amacı ve kullanıcıların özellikleri doğrultusunda farklı özelliklere sahip bu göz izleme cihazlarından hangisinin kullanılacağına karar vermek de araştırmanın başarısı açısından son derece önemlidir. İyi bir göz izleme araştırması için göz hareketlerini etkileyen faktörlerin de belirlenmesi gerekir.

\section{Göz Hareketlerini Etkileyen Faktörler}

Duerrschmid ve Danner literatürdeki çalışmaları derleyerek göz hareketlerini etkileyen faktörleri belirlemişlerdir. Bu faktörler aşağıdaki gibi özetlenebilir (2018, s. 288291):

- $\quad$ Bireye özgü faktörler (kişilik özellikleri, bireysel tercihler, sosyo-kültürel özellikler, cinsiyet, ihtiyaçlar, hedefler, inanışlar vb.), karmaşıklığı vb.),

Gözlemlenen nesneye özgü özellikler (görsellerin sayısı, rengi, şekli,

- Katılımciya verilen görevin türü,

- Katılımciya verilen görevin zorluğu.

Yukarıdaki değişkenlerden özellikle cinsiyet değişkeni bağlamında kadınların metinsel bilgiye daha dikkatli edinmeye eğilimliyken; erkeklerin önce fotoğraflara yöneldikleri, daha az metin okuduklarına vurgu yapılmaktadır (Schiessl vd., 2003, s. 5). Gerçekten göz hareketlerini etkileyen bu faktörler araştırmada doğru tasarlandığında reklam ve halkla ilişkiler uzmanlarına oldukça faydalı sonuçlar verecektir. Bu faydalı sonuçlar da kurumlar ve markalar açısından başarılı kampanyalar ortaya çıkarmalarını sağlayacaktır. Şüphesiz bu başarılı kampanyalar için göz izleme araştırmalarında uygulanan göz izleme prosedürünün önemi yadsınamaz bir gerçektir.

\section{Tipik Bir Göz İzleme Prosedürü}

Göz izleme yöntemi teknik bilgi ve odaklanma isteyen bir yöntemdir. Örneğin; bu yöntemde araştırmacılar, Tobii ${ }^{\mathrm{TM}}$ T60 ekran temelli göz izleyiciler gibi cihazları kullanarak göz hareketlerini kaydetmekte, bu cihazlara güç sağlamak için masa üstü bilgisayarlardan faydalanmaktadırlar. Kullanılacak görseller Tobii ${ }^{\mathrm{TM}}$ yazılımı gibi yazılımlara aktarılmakta, göz izleyici cihazın yazılımı katılımcılardan elde edilen verilerden 1sı haritası ve istatistiki 
bilgiler sağlamaktadır. İstatistiksel veriler, Microsoft Excel dosyalarına Tobii ${ }^{\mathrm{TM}}$ yazılım programı aracılığıyla aktarılmaktadır (Lierle, 2017, s. 12). Gwizdka ve arkadaşları bu teknik süreç içerisinde gerçekleştirilebilecek tipik bir göz izleme prosedürünün aşamalarını aşağıdaki gibi sıralamışlardır (2019, s. 745-746):

- Göz izleme verilerinin toplanması, her bir katılımcı için yapılması gereken bir kalibrasyon (calibration) prosedürü ile başlar. Katılımcıların monitörden yaklaşık 50-70 cm uzakta (bu mesafe göz izleyici modeline göre değişebilmektedir) oturmaları gerekir. Kalibrasyon, katılımcıların ekrandaki hareketli bir noktaya bakmalarını gerektirir. Katılımcılardan noktayı gözleriyle takip etmeleri, nokta herhangi bir yerde durduğu anda da o alana sabitlenip sabit bir şekilde o alana bakmaları istenir. Giyilebilir göz izleyiciler için prosedür benzerdir ve katılımcıların çevrelerindeki özel noktalara bakmalarını gerektirir. Bazı katılımcılar için kalibrasyon başarıyla tamamlanmayabilir. Düşük göz kapakları, uzun kirpikler, maskaralı gözler (katılımcılardan özellikle makyaj yapmamaları istenir), kontakt lenslerin altındaki hava kabarcıklarının ek yansımalara neden olması vb. bu durum üzerinde etkili olabilir. Kalibrasyon başarıyla tamamlandıktan sonra veriler kayıt edilmeye başlar.

- $\quad$ Monitör temelli göz izleyicilerde ortam ışığının değiştirilmemesi gerekir. $\mathrm{Bu}$ yüzden genelde penceresiz ortamda floresan 1şıklar kullanılır. Katılımcıların göz izleyici ile konumunun aynı kalması sağlanmalıdır. Yani katılımcılar sandalyeyi hareket ettirmemeli veya duruşlarını değiştirmemelidir. Bununla birlikte, boyutuna bağlı olarak küçük bir başlık kutusu içinde kafa hareketine izin verilir: Daha küçük, düşük kaliteli göz izleyiciler için tipik olarak $25 \times 11 \mathrm{~cm}$ arasında değişen göz izleyici modeli; üst düzey göz takip cihazları için $50 \times 36$ hatta $40 \times 90 \mathrm{~cm}$ 'ye kadar değişen göz izleyici modeli. İzleme koşulları değişirse, katılımcının yeniden kalibre edilmesi gerekir.

- $\quad$ Diğer bir husus, göz izleyicinin doğruluğudur. Tipik izleyici doğruluğu 0,4 ila 1 derecelik görüş açısı aralığındadır (modele bağlı olarak). Tipik görüntülemede monitörden uzaklık (65 cm), bu yaklaşık yarım inç veya $1,2 \mathrm{~cm}$ 'ye karşılık gelir.

- Veri toplama tamamlandiktan sonra analize geçmeden önce verilerin temizlenmesi gerekir. Göz izleme verilerinin temizlenmesindeki ana hususlar arasında kalibrasyon kalitesi ve kayıp veri yer almaktadır. Kayıp verinin nedenleri arasında katılımcının göz kırpması, aşağı doğru ve ekrandan uzağa bakması gibi nedenler vardır. Araştırmacılar önceden kabul edilebilir kayıp veri seviyesi için bir eşik belirlemelidir. Tipik olarak, bu seviyeler yüzde 10 ila 30 arasında ayarlanır.

- Veriler temizledikten sonra, araştırmacılar veri analizine geçebilirler. Burada niteliksel ve niceliksel analizler gerçekleştirilebilir, çeşitli yazılımlardan faydalanılabilir.

Göz izleme araştırmasında bu göz izleme prosedürleri ne kadar dikkatle uygulanırsa o kadar etkili ve doğru sonuçlar elde edilir. Göz izleme çalışmalarına ilişkin bu genel açıklamalar doğrultusunda reklam ve halkla ilişkiler alanındaki kullanımlarından da söz etmekte yarar vardır.

\section{Göz İzleme Yönteminde Kayıp Veri, Veri Kalitesi ve Geçerlilik Olgusu}

Göz izleme yönteminde, veri kalitesi için kayıp veri yönetiminin dikkate alınması gerekmektedir. Katılımcıların gözlerini kapamaları, gözlerini kırpmaları, hapşırmaları ya da bakışlarını uyarıcıdan uzaklaştırmaları gibi nedenlerden kayıp veri noktaları 
oluşmaktadır (King vd., 2019, s. 153). Kayıp veri oranının \% 10-30 arası olması kabul edilebilir olarak değerlendirilmektedir (Gwizdka vd., 2019, s. 746). Bu noktada, araştırmada yakalanan kayıp veri miktarının bu aralıklarda olması beklenmektedir.

Göz izleme çalışmalarında dikkat edilmesi gereken konulardan bir diğeri ekolojik geçerliliğin sağlanmasıdır. Göz izleme çalışmaları laboratuvar ortamında gerçekleştirilen çalışmalar oldukları için ekolojik geçerliliğe yönelik bazı tehditler taşıma riski bulunmaktadır. Burada, odadaki aydınlatmanın doğru ayarlanması, tüm testleri aynı araştırmacının uygulaması ve aynı anda odaya yalnızca bir katılımcının girmesine izin verilmesi gibi bazı kontroller gerçekleştirilebilmektedir (Lierle, 2017, s. 17).

Göz izleme yönteminde geçerliliği test etmenin bir diğer yolu da örtük hatırlama soruları kullanımıdır. Burada kastedilen, kişinin belirli bir alandaki bekleme süresi ve sabitlenme süresi ne kadar fazlaysa; o alanla ilgili örtük hatırlama sorularına vereceği cevapların da o kadar fazla doğru içermesidir. Bir başka deyişle, sabitlenme/bekleme süreleri ile örtük hatırlama sorularına verilen doğru cevap sayısında pozitif bir ilişkinin elde edilmesidir (Krugman vd., 1994, s. 48). Bu sayede araştırmanın geçerliliğinin artacağı varsayılmaktadır.

\section{Reklam ve Halkla İlişkiler Alanındaki Göz İzleme Çalışmalarından Örnekler}

Günümüzde, göz izleme çalışmalarından reklam, satış, halkla ilişkiler gibi pek çok alan faydalanabilmektedir (Santos vd., 2015, s. 48). Literatürde, reklam ve pazarlama alanına dair göz izleme çalışmalarının 1920'li yıllara kadar dayandığı görülmektedir. Bilinen ilk basılı reklamın göz izleme analizi 1924 yılında Nixon tarafından dergi reklamı okuyan tüketicilerle gerçekleştirilmiştir. Çalışma boyunca Nixon kendisini perde arkasındaki bir kutuda saklanmış ve tüketicileri izlemiştir. 1940 yılında Karslake, özel bir göz kamerası ile Saturday Evening Post'ta yer alan reklamlar üzerinde okuyucuların göz hareketlerine dair veriler toplamıştır. 1978 yılına gelindiğinde ise Russo, GözSabitlenmeleri Dünyay Kurtarabilir (Eye-Fixations Can Save the World) isimli makalesinde göz izleme yönteminin pazarlama faaliyetlerinin etkililiğinin değerlendirilmesindeki önemini tartışmıştır. Bu makaleden sonra göz izleme araştırmaları, basılı reklamdan, TV reklamlarına; markalamadan, eğitim mesajlarına kadar pek çok uygulamada önemli bir alan haline gelmiştir (Wedel ve Pieters, 2008, s. 129).

Halkla ilişkiler alanında göz izleme yöntemiyle gerçekleştirilmiş sınırlı sayıda çalışmanın olduğu görülmektedir. Bunlardan biri HPV aşısı hakkında bilgilendirme amacı taşıyan bir halk sağlığı kampanyasında görsel dikkatin aşılama mesajlarının hatırlanırlığı, bilgilendiricilik değeri ve davranışsal niyet üzerindeki etkisini belirleme amacıyla gerçekleştirilen deneysel bir çalışma olmuştur. Çalışma sonucunda görsel türünün hatırlama bilgilendiricilik değeri ve aşı olma niyeti üzerinde etkili olduğu görülmüştür (Avery ve Park, 2018, s. 321). Ayrıca, paydaş bakış açısıyla daha üstün kurumsal sosyal sorumluluk rapor türünün belirlenmesi amacıyla gerçekleştirilmiş bir çalışma da bulunmaktadır (Litfin vd., 2017, s. 30).

Marka yerleştirme gösterim türlerinin izleyicilerin görsel dikkati, ikna bilgisi kullanımı ve marka tepkileri üzerindeki etkisinin incelendiği bir araştırmada göz izleme yöntemiyle marka yerleştirmenin olduğunu belirten logo ile beraber marka yerleştirmenin olduğunu ifade eden bir uyarı yazısı kullanıldığında reklam farkındalığının daha fazla arttığı ortaya çıkartılmıştır (Boerman vd., 2015, s. 196).

Web dizinlerinin reklam konumunun ve renginin kullanıcıların dikkatini nasıl etkilediğini araştırmak için gerçekleştirilen bir çalışmada göz izleme yöntemi 
kullanılmıştır. Çalışma ile kullanıcıların ilk sabitlenme noktalarının ekranın merkezi olduğu orta alanda ve sol üst köşede yer alan reklam bağlantılarının, kullanıcıların dikkatini artıracağı belirlenmiştir (Cao vd., 2019, s. s. 89).

Genç kadınların moda reklamlarına görsel olarak nasıl katıldıklarının incelendiği bir göz izleme çalışmasında kişisel özelliklerin göz hareketlerinde bireysel farklılıkları etkileyip etkilemediğine bakılmıştır. Sonuçta, ince beden içselleştirmesi yapanların modele daha uzun ve daha sık baktıkları görülmüştür (Ju ve Johnson, 2010, s. 159).

Tüketicilerin ürün sayfalarını nasıl incelediklerinin araştırıldığı bir çalışmada, en çok ürünle ilgili bilgilerin tüketiciler için önemli olduğu görülmüştür (Maslowska vd., 2020, s. 282).

Bir reklamın web sayfasındaki konumunun reklam körlüğü üzerindeki etkisi üzerine gerçekleştirilen bir göz izleme çalışmasında, sağ taraftaki yazılı reklamların sayfanın yukarısındaki reklamlardan daha fazla kaçırıldığı belirlenmiştir (Owens vd., 2011, s. 172).

E-ticaret sitelerindeki reklam körlüğünü belirlemek amacıyla gerçekleştirilen bir başka göz izleme çalışmasında da banner körlüğünün en fazla sayfanın sağ tarafındaki reklamlara karş1 olduğu görülmüştür (Resnick ve Albert, 2014, s. 209).

Dikkat düzeylerinin kullanıcıları nasıl etkilediğini araştırmak için gerçekleştirilen bir çalışmada ise, bir reklama maruz kalma sonucu ortaya çıkan dikkat düzeyini ölçmek için göz izleme yönteminden faydalanılmıştır. Çalışmada ayrıca banner reklamlardaki animasyonun dikkat üzerindeki etkisi incelenmiştir. Araştırma sonucunda, banner reklamlardaki animasyonun, statik reklamlara göre daha az dikkat çektiği ve dikkatin hafıza üzerindeki olumlu etkisini azalttığg görülmüştür (Lee ve Ahn, 2012, s. 119).

Sağlık iletişimi çalışmaları kapsamında tütün ürünleri reklamlarının gençler tarafindan nasıl görüldüğünün incelendiği bir başka araştırmada, göz izleme yöntemiyle katılımcıların toplam reklam süresinin ortalama $\% 8$ 'ini gördügü̈, $\% 43.6$ katılımcının ürünlerin üzerindeki sağlık uyarılarını hiç görmediği belirlenmiştir (Fisher vd., 1989, s. 84). Benzer bir araştırmada uyarıdaki metin miktarının, yaratıcı kavram kullanımının ve ürün ilgi düzeyinin bu uyarılara yönelik dikkat üzerinde etkili olduğu belirlenmiştir (Fox vd., s. 1998, s. 65). Dergi alkol reklamlarındaki sorumluluk mesajlarına ('sorumlu iç!' gibi) gençlerin dikkatinin incelendiği bir diğer göz izleme çalışmasında da uyarı mesajlarının ve ilgili görsellerinin reklamda en az siklıkta görülen alanlar olduğu, gençlerin toplam sabitlenme sürelerinin yalnızca \%7'lik bir kısmında bu mesajlarda sabitlendikleri, katılımcıların en sık içeceğin şişesini, ürün logosuna baktıkları görülmüştür (Thomsen ve Fulton, 2007, s. 27).

Web sitelerinde kullanıcıların reklam görmekten kaçınıp kaçınmadıklarının incelendiği bir başka çalışmada katılımcıların site ziyaretleri boyunca en az bir kez reklama sabitlendikleri, editoryal içerik ile uyumlu reklamların, uyumlu olmayanlara göre daha fazla hatırlandıkları görülmüştür (Hervet vd., 2011, s. 708).

Reklama yönelik dikkat üzerine gerçekleştirilen başka bir göz izleme çalışmasında, dergi reklamlarında modellerin ürüne ve okuyucuya bakışına göre dikkat kıyaslaması yapılmış ve modelin ürüne baktığı reklamlarda katılımcıların ürüne, logoya ve genel olarak reklamın tamamına daha uzun süre baktıkları görülmüştür (Hutton ve Nolte, 2011, s. 887).

Reklamların izleyicilerdeki duyguyu ve reklamı izlemeye yönelik dikkati nasıl güçlendirebileceği üzerine gerçekleştirilen bir göz izleme çalışmasında sürpriz ve eğlence 
unsurlarının dikkatin sabitlenmesini ve izleyicinin tutulabilmesi (retain) konularında etkili olduğu görülmüş̧ür (Teixeria vd., 2012, s. 144).

\section{Sonuç ve Öneriler}

Günümüzde bireyler her geçen gün daha fazla marka ve kurum mesajlarına maruz bırakılmaktadır. Böylesi bir ortamda hedef kitlenin dikkatini çekmek ve görsel algı alanına ulaşabilmek daha da zorlaşmaktadır. Bu noktada, göz izleme yönteminin önemi hem iletişim profesyonelleri hem de araştırmacıları için artmaktadır. Göz izleme yöntemine dair genel bir çerçevenin çizilmeye çalışıldığı bu araştırmada ayrıca yöntemin birer iletişim alt disiplinleri olan reklam ve halkla ilişkiler alanına dair çalışma örneklerine de değinilmiştir. $\mathrm{Bu}$ bölümde reklam alanında pek çok çalışma gerçekleştirilmesine rağmen halkla ilişkiler alanındaki çalışmaların sınırlı kaldığı belirlenmiştir. Özellikle bu yöntem sayesinde hedef kitlenin ilgi alanlarının (AOI) belirlenmesi ile kurum kültürü kapsamında değerlendirilebilecek kurumsal logo, slogan gibi unsurların iletişim materyalleri üzerinde en uygun nereye konumlandırılması gerektiği gibi konularda halkla ilişkiler alanına önemli katkılar sağlanabileceği görülmüştür. Aynı zamanda, geleneksel ve dijital mecralarda kurumlar için hazırlanan haber içeriklerinde başlı̆̆ın nereye yazılması gerektiği, hedef kitlenin hangi içeriklerde ne kadar süre geçirebileceği, iletişim bağlantılarının içeriğin neresine eklenmesi gerektiği gibi konularda da yol gösterici olabileceği söylenebilir. Yine, hangi içeriklerin hedef kitlenin ilgisini daha çok çektiğinin sabitlenme noktaları ve süreleri (fixation points and fixation duration) gibi göz izleme verileri ile belirlenmesi sayesinde doğru hedef kitleye doğru içeriklerin hazırlanması mümkün olabilecektir. Hedef kitlenin göz hareketlerini etkileyen faktörlerin bilinmesi ve bu faktörler doğrultusunda görsel kampanya tasarımlarının gerçekleştirilmesi de kurumlar ve markaların kampanya tasarımlarını ve sonuçlarını olumlu yönde etkileyecektir. Bu nedenlerden dolayı göz izleme yöntemi özellikle halkla ilişkiler alanında daha da önem kazanacaktır.

\section{Extended Abstract}

Today, individuals are constantly exposed to a variety of content from brands. At this point, it becomes more and more difficult for individuals to notice these contents, to pay attention to these contents, to perceive and remember the messages in these contents. The starting point of awareness and subsequent processes such as perception and remembering is predominantly the visual mechanism. Therefore, eye tracking emerges as a remarkable and increasingly popular value for communication research.

Eye tracking can be defined as the method in which the eye movements of the individual are measured for the stimuli in visual perception in general. In the early studies, it is stated that the movements were taken in the form of video recording. Again, in this period, the areas where eye tracking was mainly used were reader studies and studies in the field of psychology. Today, this method is used in a wide variety of fields, from sponsorship studies to internet advertising, from health communication to corporate social responsibility research, from package design to physical shopping processes in markets.

The data provided by the devices used in the eye tracking method to the researchers have a great impact on the results that is obtained from the study. At this point, the metrics used in the method are seen as another important issue. These metrics can be categorized in four main categories. These categories are fixation-based metrics, time-based metrics, movement-based metrics and other metrics.In fixation-based metrics, there are fixation frecuency, fixation count, location of the first fixation, observation/visit/dwell count. In time-based metrics, there are fixation duration/dwell time, observation/visit/dwell duration, total fixation duration ve time of the first fixation. In movement-based metrics, there are 
saccades and scanpath. In other metrics, there are pupil dilation, blink rate and participant $\%$.

Basically, three methods are used to visualize eye tracking data. The first of these is the representation of visual data in the form of a heat map. In this method, the most frequently viewed areas are shown in red, the less frequently viewed areas in yellow, and the less frequently viewed areas in green. In areas where the eye of the individual never goes, no color is used. An important tool for the analysis of eye movement data is the use of areas of interest (AOIs) that define key areas of the image that need to be analyzed separately. Areas of interest can be plotted on the image using eye tracker software, and then eye tracking data for defined areas can be statistically analyzed. Another option for visualizing eye tracking data is to show fixations on a timeline. Such gaze sequences show a participant's scan path and search behavior. Each fixation is represented as a point, the number inside the dots represents the order in which fixation occurs, and the diameter of the spot represents the length of fixation in terms of duration.

Fixation identification algorithms have a special importance in eye tracking method. The most known and used algorithms: I-VT, I-HMM, I-DT, I-MST and I-AOI. These algorithms are classified into two basic categories, spatial and temporal. The spatial category is divided into three categories: velocity-based, dispersion-based and area-based. The temporal category, on the other hand, is divided into two subcategories as duration sensitive and locally adaptive.

The concept of attention is one of the most studied concepts in eye tracking. It is stated that there is a relationship between the point of view of the person and his cognitive processes and attention level. At this point, it is thought that an objective measurement of attention is obtained with eye tracking as a neuroscientific research method. Moreover, it is pointed out that with this method, not only the visual attention of the viewers towards the stimulus can be measured, but also their attention towards a particular element in a particular stimulus can be measured.

In parallel with the importance of eye tracking method, eye tracking devices have also developed over time. In the beginning, expensive and useless devices have started to be replaced by devices that are more affordable, more useful and can provide more detailed data. The devices used in the eye tracking are generally divided into three as screen-based eye trackers, peripheral eye-tracking modules and wearable eye trackers. Among the eye tracking system manufacturers, ASL- Applied Science Laboratories-, iMotions A/S Biometric Research Platform, Interactive Minds Dresden GmbH, SMI SensoMotoric Instruments GmbH, SR Research (EyeLink) and Tobii Technology become prominent.

A wide variety of factors have an effect on the eye movements of individuals. Tese factors are individual factors (personality characteristics, individual preferences, sociocultural characteristics, gender, needs, goals, beliefs, etc.), characteristics specific to the observed object (number, color, shape, complexity of the images, etc.), type of task assigned to the participant, given to the participant the difficulty of the task.

A typical eye tracking procedure begins with calibration. Low eyelids, long eyelashes, eyes with mascara (participants are specifically asked not to wear make-up), air bubbles under contact lenses causing additional reflections, etc. may cause the calibration process to fail. After the calibration process, the recording starts. This is the point where the data collection process begins. In the data collection process, it is of great importance to keep the participant's position with the eye tracker constant, to set the ambient lighting correctly, and to have the accuracy of the eye tracker within the appropriate viewing angle range. After data collection is complete, the data must be cleaned before proceeding to 
analysis. Key considerations in clearing eye tracking data include calibration quality and missing data. Researchers should set a threshold for the acceptable level of missing data in advance. Typically, these levels are set between 10 and 30 percent. After cleaning the data, researchers can move on to data analysis. Here, qualitative and quantitative analyzes can be performed and various software can be used.

When we look at the eye tracking studies carried out in the field of advertising and public relations, it is seen that eye tracking studies are mainly carried out in the field of advertising, and there are very limited studies in the field of public relations. These studies also focused mainly on the field of health communication.

The issue of missing data, data quality and validity in eye tracking method has been another subject discussed in this study. In eye tracking method, missing data management should be considered for data quality. Missing data points occur because participants close their eyes, blink, sneeze, or turn their gaze away from the stimulus. Another issue to be considered in eye tracking studies is ensuring ecological validity. Since eye tracking studies are carried out in a laboratory environment, there is a risk of some threats to ecological validity. Another way to test the validity of the eye tracking method is the use of recall questions. All these issues were discussed in this stidy and some important recommendations were presented to the academy and the communication proffesionals.

\section{Kaynakça}

Avery, J. E. and Park, s. (2018). HPV vaccination campaign fear visuals: An eye tracking study exploring effects of visual attention and type on message informative value, recall, and behavioral intentions. Public Relations Review, 44, 321-330.

Boerman, C. S., van Reijmersdal, A. E. and Neijens, C., P. (2015). Using eye tracking to understand the effects of brand placement disclouse types in television programs. Journal of Advertising, 44(3), 196-207.

Cantoni, V. and Porta, M., Ravarelli, A. (2011). Applying on-line newspaper design principles to e-Learning: An eye-tracking study focused on multimedia. Communication \& Cognition, 44, 1-15.

Cao, Y., Qu, Q., Duffy, G. V. and Ding, Y. (2019). Attention for web directory advertisements: A top-down or bottom-up process? International Journal of Human-Computer Interaction, 35(1), 89-98.

Chae, S. W. and Lee, K. C. (2013). Exploring the effect of the human brand on consumers' decision quality in online shopping: An eye tracking approach. Online Information Review, 37, 83-100.

Duchowski, Andrew T. (2002). A breadth-first survey of eye tracking applications. Behavior Research Methods, Instruments, and Computers, 34(4), 455-470.

Duerrschmid, K. and Danner, L. (2018). Eye Tracking in Consumer Research. Methods in Consumer Research, 2, 279-318.

Fox. J. R., Krugman, M. D., Fletcher, E. J. and Fischer, M. P. (1998). Adolescents' attention to beer and cigarette print ads and associated product warnings. Journal of Advertising, 27(3): 57-68.

Gwizdka, J., Zhang, Y. and Dillon, A. (2019). Using the eye tracking method to study consumer online health information search behaviour. Journal of Information Management, 71(6), 739-754. 
Hervet, G., Guérard, K., Tremblay, S. and Chtourou, M. S. (2011). Is banner blindness genuine? Eye tracking internet text advertising. Applied Cognitive Psychology, 25, $708-716$.

Holsanova, J., Holmqvist, K. and Rahm, H. (2006). Entry Points and Reading Paths on Newspaper Spreads: Comparing a Semiotic Analysis with eye tracking Measurements. Visual Communications, 5(1), 65-93.

Hutton, S. B. and Nolte, S. (2011). The effect of gaze cues on attention to print advertisements. Applied Cognitive Psychology, 25, 887-892.

Ju, H. and Johnson, P. K. K. (2010). Fashion advertisiments and young women: Determining visual attention using eye tracking. Clothing\&Textiles Research Journal, 28(3), 159-173.

King, J. A., Bol, N., Cummins, G. R. and John, K. K. (2019). Improving visual behavior research in communication science: An overview, review, and reporting recommendations for using eye-tracking methods. Communication Methods and Measures, 13(3), 149-177.

Krugman, M. D., Fox, J. R., Fletcher, E. J., Fischer, M. P. and Rojas, H. T. (1994). Do adolescents attend to warnings in cigaretter advertising? An eye-tracking approach. Journal of Advertising Research, November/December, 39-52.

Kumar, N., Maheshwari, V. and Kumar, J. (2016). A comparative study of user experience in online social media branding web pages using eye tracker. International Conference on Advances in Human Machine Interaction. 1-8.

Lee, J. and Ahn, J. (2012). Attention to banner ads and their effectiveness: An eye-tracking approach. International Journal of Electronic Commerce, 17(1), 119-137.

Lierle, A. (2017). The view: An eye-tracking study of print advertisements. The Degree of Master of Science. Oklahoma State University.

Litfin, T., Meeh-bunse, G., Luer, K. and Teckert, Ö. (2017). Corporate social responsibility reporting-a stakeholder's perspective approach. Business Systems Research, 8(1), $30-42$.

Maslowska, E., Segijn, M. C., Vakeel, A. K. and Viswanathan, V. (2020). How consumers attend to online reviews: an eye-tracking and network analysis approach. International Journal of Advertising, 39(2), 282-306.

Myers, A. G., Sherman, R. K. and Stark, L. (1991). Eye monitor. microcomputer-based instrument uses an internal model to track the eye. IEEE Computer Magazine, 1421.

Owens, W. J., Chaparro, S. B. and Palmer, M. E. (2011). Text advertising blindness: The new banner blindness? Journal of Usability Studies. 6(3), 172-197.

Pozharliev, R., Verbeke, JMI. W. and Bagozzi, P. R. (2017). Social Consumer Neuroscience: Neurophysiological Measures of Advertising Effectiveness in a Social Context. Journal of Advertising, 46(3), 351-362.

Resnick, M. and Albert, W. (2014). The impact of advertising location and user task on the emergence of banner ad blindness: An eye-tracking study. International Journal of Human-Computer Interaction, 30(3), 206-219. 
Rumpf, C. and Breuer, C. (2018). Focus on brand choice: Assessing the behavioral response to sponsorship-linked communication. Journal of Sport Management, 32, 531-541.

Salvucci, D. D. and Goldberg, H. J. (2000). Identifying fixations and saccades in eyetracking protocols. Eye Tracking Research \& Applications Symposium. 71-78.

Santos, dos J. O. de R., Oliveira, de C. H. J., Rocha, B. J. and Giraldi, E. M. de J. (2015). Eye tracking in neuromarketing: A research agenda for marketing studies. International Journal of Psychological Studies, 7(1), 32-42.

Schiessl, M., Duda, S., Thölke, A. and Fischer, R. (2003). Eye tracking and its application in usability and media research. MMI-interaktiv Journal, 1-10.

Teixeira, T., Wedel, M. and Pieters, R. (2012). Emotion-induced engagement in Internet video advertisements. Journal of Marketing Research, 49, 144-159.

Thomsen, S. R. P. D. and Fulton, K. B. A. (2007). Adolescents' attention to responsibility messages in magazine alcohol advertisements: An eye-tracking approach. Journal of Adolescent Health, 41, 27-34.

Wästlund, E., Shams, P., Löfgren, M., Witell, L. and Gustafsson, A. (2010). Consumer perception at point of purchase: Evaluating proposed package designs in an eyetracking lab. Journal of Business and Retail Management Research, 5(1), 42-51.

Wedel, M. and Pieters, R. (2008) A Review of Eye-Tracking Research in Marketing. In Malhotra, N. (Ed.) Review of Marketing Research, (p. 123-147). Bingley: Emerald Group Publishing Limited.

https://www.tobiipro.com/product-listing/tobii-pro-glasses-3/ (Erişim tarihi: 20.07.2021).

https://www.sr-research.com/eyelink-portable-duo/ (Erişim tarihi: 20. 07. 2021).

https://imotions.com/blog/how-to-do-product-testing-in-store-shelf-testing/ (Erişim tarihi: 20.07.2021).

https://www.interactive-minds.com/ (Erişim tarihi: 20.07.2021).

Araştırmacı Katkı Oranı: Araştırmacılar çalışmaya eşit oranda katkı sunmuştur.

Destekleyen Kurum/Kuruluşlar: Herhangi bir kurum/kuruluştan destek alınmamıştır.

Çıkar Çatışması: Herhangi bir çıkar çatışması bulunmamaktadır. 